\title{
Development and Validation of Academic Writing Textbook Based on Process Genre Approach for University Students
}

\author{
Helaluddin', Mohammed H. Al Aqad², Hengki Wijaya3, Jusmianti Anwar4, \\ Nyayu Lulu Nadya5, and Syafryadin' 6
}

DOI: $10.35445 /$ alishlah.v13i2.766

Article Info

Keywords:

Development;

Validation;

Academic Writing;

Process Genre

Approach;

Kata kunci:

Pengembangan;

Validasi;

Menulis Akademik;

Pendekatan Proses

Genre;

\section{Abstract}

The textbook is a practical learning tool for improving student writing skills; however, not all students learn from a textbook. For this reason, a lecturer must be able to design a textbook according to the needs of students. This paper describes developing and validating academic writing textbooks with a process genre approach in tertiary institutions. This research is part of the research \& development process, consisting of three phases: need assessment, design, and validation. Five experts were appointed to validate this academic writing textbook. Content Validity Index (CVI) is used to calculate the validity of textbooks quantitatively, with a score above 0.79 considered to meet the criteria. The validity test results state that the CVI of an academic writing textbook is 0.9 , with a few revisions based on expert input and suggestions. These findings indicate that this textbook has good validity and reliability and can write in college.

\begin{abstract}
Abstrak
Buku teks merupakan salah satu perangkat pembelajaran yang digunakan untuk dapat meningkatkan keterampilan menulis mahasiswa, namun, tidak semua mahasiswa belajar dari buku teks. Untuk alasan itulah, seorang dosen harus mampu mendesain buku teks sesuai dengan kebutuhan mahasiswa. Artikel ini mendeskripsikan proses pengembangan dan validasi buku teks menulis akademik dengan pendekatan proses genre di perguruan tinggi. Studi ini merupakan bagian dari proses penelitian \& pengembangan yang berisi tiga fase, yaitu fase analisis kebutuhan, mendesain produk, dan validasi. Lima pakar ditunjuk untuk memvalidasi buku teks menulis akademik ini. Indeks Validitas Konten (IVK) digunakan untuk menghitung validitas buku teks secara kuantitatif dengan skor di atas 0,79 yang memenuhi kriteria. Hasil tes validitas menunjukkan bahwa indeks validitas konten buku teks menulis akademik adalah sebesar 0,9 dengan sedikit revisi yang disarankan oleh para pakar. Hasil penelitian menunjukkan bahwa buku teks ini memiliki validitas dan reliabilitas
\end{abstract}

\footnotetext{
${ }^{1}$ UIN Sultan Maulana Hasanuddin Banten, Indonesia

Email: helaluddin@uinbanten@ac.id

2 Management and Science University, Malaysia

Email: alakkadmohmad@yahoo.com

3 Sekolah Tinggi Filsafat Jaffray Makassar, Indonesia

Email: hengkilily1988@gmail.com

4 Pascasarjana Universitas Negeri Makassar, Indonesia

Email: just.myantii@gmail.com

5 Universitas Tridinanti Palembang, Indonesia

Email: nyayu_lulu_nadya@univ-tridinanti.ac.id

${ }^{6}$ Universtas Bengkulu, Indonesia

Email: syafryadin@unib.ac.id
} 
yang baik dan dapat digunakan dalam pembelajaran menulis di perguruan tinggi.

\section{INTRODUCTION}

Over the past few decades, the study of writing learning has become a mainstream part of the discipline of applied linguistics (Zhao, 2017). Academic writing learning is currently recognized as one of the learning levels with severe challenges educators must face in tertiary institutions (Ganobcsik-Williams, 2006; Alabere \& Shapii, 2019). Due to the need for analytic argumentation that must be taught to students in such learning (Andrews, 2009; Lilis \& Turner, 2001). In other words, writing is not just an activity of putting ideas into writing but also the process of giving an argument so that the reader believes it.

Writing competence can be said to be a very complex and complicated competency. In addition to having to master a varied vocabulary, at the same time, students also need a combination of three language skills at once, both reading, listening, and speaking skills (Babalola \& Litinin, 2012). This writing competence consists of two main activities: activities that emphasize the language element and the idea element (Kuswandari et al., 2018).

When viewed from the target to be achieved, writing learning is still focused on the declarative level or learning level, which only discusses knowledge (what writing is about) and procedural knowledge level or knowing how to write (Tao quoted Yanti et al., 2018). In other words, learning to write at this time has not touched another level that has a more important role, namely the contextual level. This level teaches students about when and how to write it.

In some studies, students' writing outcomes, especially academic writing in Indonesian language subjects, are low. The weak performance needs urgent attention for stakeholders in the campus world, especially for teachers (Mccrimmon, 2005; Jahin, 2012; Sarala et al., 2015). Much of the literature reports the results of his studies that student writing is judged lacking in aspects: (1) focus, (2) themes developed, (3) structure, (4) persuasive arguments or analysis, (5) synthesis \& analysis of authority, (6) errors in citation, (7) grammar, (8) spelling, and (9) punctuation (Knight et al., 2018). Many facts reveal that students have not been taught to write academically well or attend workshops before registering for college (Keong \& Mussa, 2015).

The low performance of academic writing can also be caused by the learning approach used by teachers (Babalola \& Litinin, 2012; Akinwamide, 2012; Ivanic \& Lea, 2006). In other words, there are still many teachers who use sub-optimal learning approaches (Heffernan, 2006). For this reason, experts recommend that teachers use a combined approach, one of which is a process-genre approach (Dewle, 2017). This approach makes it possible for students to learn between the aims and forms of a particular genre of writing because they use the stages of prewriting, composing, revising, and editing (Tesfie, 2017).

Regarding the process genre approach in learning to write, there are several previous studies conducted by researchers. Most of the research conducted is related to classroom action research (Yanghee \& Jiyoung, 2005; Amine \& Faiza, 2018; Gupitasari, 2013). Besides, analysis with qualitative design in learning to write is also carried out by $\mathrm{Xu} \& \mathrm{Xuemei}$ (2018). There has been no research that develops learning textbooks using the process genre approach from some of these studies.

In practice, many lecturers design their textbooks without paying attention to the needs of students. For this reason, the development of textbooks using needs analysis that involves teachers and students needs to be done immediately to improve student writing performance. The involvement of these students is based on the fact that they are active members in tertiary institutions need to be included in the process of forming the context of learning in the classroom (Cothran et al., 2003). There are three problem formulations in this study: (1) how is the analysis of needs in developing academic writing textbooks with the process genre approach? (2) how is the 
design of academic writing textbooks with the process genre approach? and (3) how is the validity of the academic writing textbook with the process genre approach?

\section{METHODS}

\section{Research Design \& Participants}

This research was conducted through three phases: the define, design, and development phases, which refer to the 4D theory by Thiagarajan, Semmel, \& Semmel (1974). There are three groups of participants involved in this study, namely: (1) 85 students from the S1 group, (2) lecturer group by five people, and (3) expert group by five people. In this study, the researchers used a purposive sampling technique in determining the participants involved. This sampling technique is used to select participants by using specific considerations. This means that using this purposive sampling technique has a higher level of compatibility between the sample and the research objectives to increase the accuracy of the research and the reliability of the data and results (Taherdost, 2016).

\section{Research Procedure}

\section{Phase I: Need Analysis}

This phase is the initial phase in gathering information related to the needs and problems lecturers and students face in writing. There are two types of research instruments used in this phase, namely questionnaires and semi-structured interviews. The questionnaire instrument was distributed to 85 students in several Banten Province, Indonesia (UIN Sultan Maulana Hasanuddin Banten, Serang Raya University, Bina Bangsa University, \& Banten Jaya University). Furthermore, interview techniques were used for five lecturers who taught Indonesian language courses.

Phase II: Design

After the need analysis phase is completed, the following research stage is the design stage. At this stage, the researcher designs and develops an academic writing textbook with a genre process approach based on the needs analysis results. The design phase includes several activities, such as deciding the format of the textbook, writing the textbook, and the initial revision of the draft textbook.

Phase III: Validation

In the validation stage, the textbook is assessed and evaluated by five experts using a validation sheet. Validation is carried out to assess the elements of content eligibility, presentation, language, and student assignments. Researchers used validation sheets that were adapted from instruments developed by National Education Standards Agency (2014). The selection of questionnaires to assess the content of textbooks is based on the nature of the survey, which can be used in collecting massive amounts of data and has power in the generalization process (Fraenkel, Wallen, \& Hyun, 2012).

\section{Data Collections}

\section{1) Questionnaire}

The questionnaire in this study was developed based on tools from Boroujeni \& Fard (2013), Ulla \& Winitkun (2017), Bada \& Okan (2000), and Hutchinson \& Waters (1987) with a focus on three aspects, namely: (1) student's language level, (2) student's language problem, and (3) student's language need. This questionnaire consists of 15 questions with answer choices and one essay question (open-ended question): "Write down your suggestions in improving the quality of academic writing learning in Indonesian courses!” Open items added to the closed questionnaire aim to clarify their answers and establish the validity of the closed questions (Singer \& Couper, 2017).

\section{2) Semi-structured Interviews}

Other instruments used in this study were semi-structured interviews. This type of discussion can be relied on to collect data through interview guides that offer informants freedom in expressing their views in their language (Wilkinson \& Birmingham, 2003). The use of this instrument is also considered to have the potential to explore personal experiences in-depth and allow researchers to 
add questions to the process of clarification and elaboration (Guthrie, 2019; Percy et al., 2015). Some of the questions in this semi-structured interview were adapted from the instruments used by several previous researchers (Coe et al., 2011; Salim et al., 2016). This instrument has five questions: (a) how long have you been teaching writing material? (b) what methods/approaches have you used in learning to write so far? (c) state the obstacles you often encounter in learning to write? (d) what do you know about the genre-process approach? (e) in your opinion, is it necessary to develop a textbook for writing with a genre-process approach, and why?

3) Textbook validation sheet

The researcher designed the validation sheet used in this validation test by giving four choices, from 1 as the lowest to 4 as the highest. This instrument has been tested before being distributed to experts and is declared valid $(\mathrm{r} \alpha=.78)$ and reliable $(\alpha=0.84)$.

\section{Data Analysis}

Data from the need's analysis phase, namely closed questionnaires, and interviews were analyzed qualitatively. The data from the two instruments are described by not relying on numbers but instead on descriptive and exploratory presentations. The Interactive Analysis Model (IA) is the analytical technique used in this study (Ananth \& Maistry, 2020). This analytical technique can produce a systematic representation of a phenomenon or a person's experience. This model consists of three stages, namely: (1) the stages of reducing the data, (2) presenting the data, and (3) concluding the results of verifying the findings (Bargate, 2014).

On the other hand, the data from the validation sheet were analyzed with a quantitative approach by presenting the average score. In this study, the type of validation used is content validation by calculating the Content validity Index. The most frequently used approach in instrument development studies is the Content Validity Index (CVI). The experts examine each unit and give a value with a scale of $1=$ not relevant, 2 = quite relevant, $3=$ relevant, and $4=$ very relevant. Furthermore, the assessment is based on a benchmark: (1) if the CVI is higher than 0.79, then the item is considered appropriate, (2) if the CVI is between 0.70-0.79, then the item needs to be revised, and (3) if CVI is less than 0.70 then the item must be eliminated (Lau et al., 2019).

\section{FINDINGS AND DISCUSSION}

\section{Description of Qualitative Findings Questionnaire Results}

Based on the data obtained through the questionnaire, the writing learning needs of the students are shown in table 1 below. The questionnaire data in this table only displays a few items that have a high frequency or percentage of students' responses. Researchers use this questionnaire because it has several reasons, one of which is validity and reliability. In other words, this questionnaire has been validated and used by several previous researchers, as mentioned in the methods section above. Thus, researchers no longer need to test the validity and reliability before distributing this questionnaire because this questionnaire has been declared valid and reliable.

Table 1. Frequency and percentage of distribution of writing learning needs from students

\begin{tabular}{llc}
\hline \multicolumn{1}{c}{ Questions } & Frequency & Percentage \\
\hline 1. & Do you like learning to write (Indonesian Language Course? & \\
like & 60 & $71 \%$ \\
2. What are the benefits of learning academic writing? & 32 & $38 \%$ \\
Career/occupation & & $42 \%$ \\
3. Writing learning at this time is following what you expect? & 36 & $56 \%$ \\
Disagree & 48 & $42 \%$ \\
4. What type of writing have you produced? Poetry & 36 & $70 \%$ \\
5. The hardest part of learning to write is...; Grammar & 59 & \\
6. An ideal textbook is needed with the best approach/genre & & \\
process approach; Strongly agree & &
\end{tabular}


7. Topics that should be raised in textbooks are; General topics (education, health, etc.)

\begin{tabular}{ll}
35 & $41 \%$ \\
64 & $75 \%$ \\
55 & $65 \%$ \\
51 & $60 \%$ \\
48 & $56 \%$ \\
45 & $53 \%$ \\
66 & $78 \%$ \\
43 & $51 \%$ \\
40 & $47 \%$ \\
\hline
\end{tabular}

8. Aspects that must be assessed in learning to write; The idea that was carried

9. The feedback you expect in learning to write; Discuss writing.

10. The need to teach the steps in learning to write; Strongly agree

11. In writing learning, the type or genre of writing to be written should be introduced; Strongly agree.

12. Writing learning is also suitable to be done in groups in the brainstorming process; Strongly agree.

13. An example text should be presented as an example in learning to write; Strongly agree.

14. We need to know who the prospective readers of the writing we produce; Strongly agree.

15. The need for publication of the writing that we have produced; Agree

Based on table 1, the researcher can detail and analyze the results of the questionnaires that students have filled out. This closed questionnaire consists of four questions to explore students' language level, 1 question about their problems in writing, and ten questions about their needs in learning to write. In addition, there is an open question that aims to gain students' perspectives and expectations in learning writing class.

Students like writing activities for various purposes. However, during their secondary education, they often write for literary genres or non-scientific writings. This means that most students are not used to writing for the academic genre. For this reason, academic writing textbooks for Indonesian language courses.

Regarding the difficulties they face in learning to write, most students experience problems in grammatical aspects. About $42 \%$ of students state that grammar is the most challenging part of learning to write. In addition, another aspect that is considered to be an obstacle in writing is their low ability to develop writing ideas. In addition, several other barriers are also chosen by several students even though the quantity is small.

The third aspect explored in the student needs analysis questionnaire is their various needs in learning to write. The majority of students agree to publish the texts they produce through multiple media, one of which is social media. Furthermore, writing learning activities are also expected by students by conducting discussions with lecturers and their colleagues. Thus, students predict the application of a genre process approach based on the answer choices.

Finally, most students expect writing lessons that consider various things on the open-ended questions in the need's analysis questionnaire. Some of the aspects they expect include: (1) lecturers must provide feedback on the texts they produce, (2) lecturers must continue to assist with student writing, and (3) lecturers must abandon the old methods in learning to write.

\section{Interview Result}

The main factor in achieving success in learning to write is identifying some of the obstacles teachers face. Some of the challenges raised by teachers can be seen in the following table.

\section{Table 2. Examples of obstacles and challenges for teachers in learning academic} writing

\begin{tabular}{ccl}
\hline No & Participants & \multicolumn{1}{c}{ Participant answer } \\
\hline 1. & P-1 & $\begin{array}{l}\text { "There are still many students who have not been able to put ideas and ideas into } \\
\text { written form." }\end{array}$ \\
\hline 2. & P-5 & $\begin{array}{l}\text { "Besides that, students also still have difficulty in giving inter-paragraph } \\
\text { integration." }\end{array}$ \\
\hline $3 \cdot$ & P-3 & $\begin{array}{l}\text { "Learning to write takes a long time because the writing process cannot be done } \\
\text { in a short time." }\end{array}$ \\
\hline
\end{tabular}


Based on table 2 above, it can be seen that the challenges in learning to write are not easy things. One of the main factors is that many students can put their ideas into writing. This happens because students are not used to writing activities when studying at the high school level. This condition was stated by the five lecturers as respondents and noted that this was the most critical problem.

The thing that is still related to the points above is the low ability of students to integrate between paragraphs so that the text looks coherent and coherent. This can also be understood because writing is an activity that requires a process and cannot be taught in a relatively fast time. Thus, extra effort is needed to be able to teach writing skills to them.

Regarding suggestions from respondents on future learning to write, many essential points need serious attention. Some of these points are: (1) textbooks must be able to help students improve their writing skills, (2) presentation of textbooks must be exciting and different from textbooks on the market, (3) aspects of assessment in learning to write must be done comprehensively covers all aspects of writing, and (4) the stages of dissemination of the final paper (publication) are needed. Some of the interview highlights can be seen in the following table 3 .

Table 3. Examples of suggestions and recommendations from lecturers

\begin{tabular}{ccc}
\hline No & Participants & \multicolumn{1}{c}{ Suggestions/recommendations } \\
\hline 1. & P-5 & $\begin{array}{l}\text { "Lecturers must design creative textbooks to arouse motivation and improve } \\
\text { writing skills." }\end{array}$ \\
\hline 2. & P-2 & $\begin{array}{l}\text { "Textbooks that are developed must have a structure/ organization, content, } \\
\text { layout, typography, illustrations, and language that is of interest to students." }\end{array}$ \\
\hline 3. & P-4 & $\begin{array}{l}\text { "Teachers must begin to change the writing learning assessment system. } \\
\text { Don't just focus on the grammatical aspects." }\end{array}$ \\
\hline
\end{tabular}

\section{Design of Textbook}

From the results of the two analytical techniques at the need assessment stage, researchers designed textbooks according to the needs of students and lecturers. Textbooks that are designed taking into account several aspects, namely content, systematic or organization, illustration, typography, layout, and language used. Some of the topics raised in writing textbooks are paragraphs, essays, book reviews, popular scientific articles, papers, journal articles, and the citation system by Mendeley. The seven topics were chosen based on the questionnaire and interviews in the need assessment phase. Types of texts from the smallest to the most complex texts are accepted because most students are not yet accustomed to producing the genre of academic texts. Instead, they are accustomed to writing poetry and other literary types while in middle and high school.

Based on the needs analysis results, a genre process approach is needed in learning to write. There are several stages designed in this academic writing textbook, namely: (1) recognizing the text, (2) analyzing the text, (3) discussing the text, (4) writing the text independently, (5) finalizing the text, and (6) publish the text. The six stages are used as a systematic textbook on each topic or subject matter. 


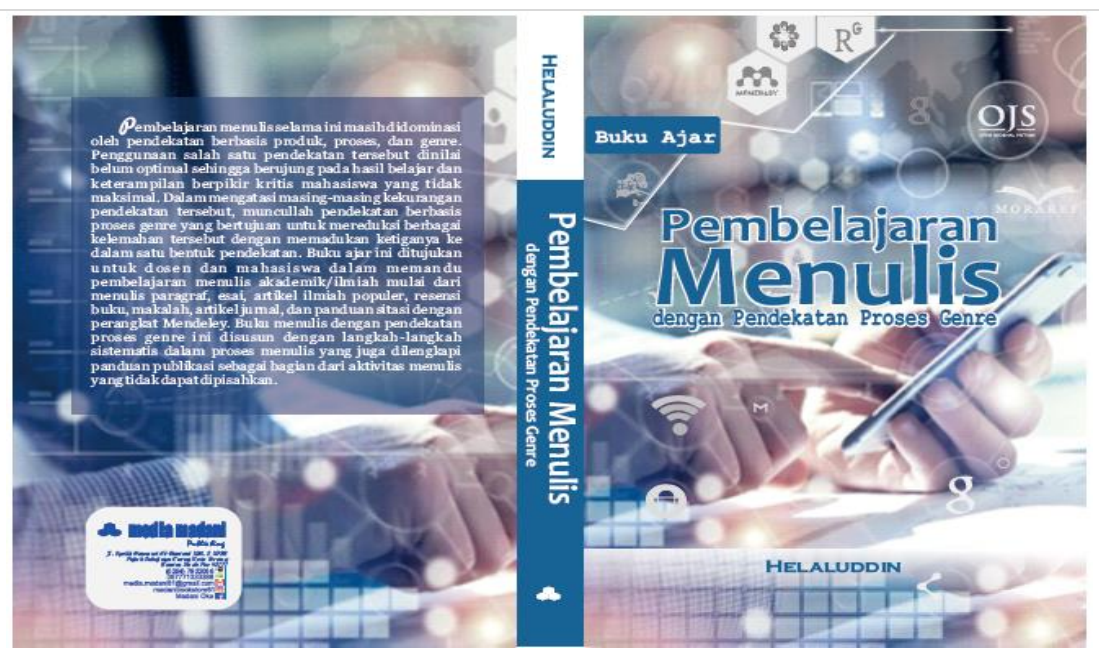

Figure 1. Cover of academic writing textbook

\section{Textbook Validation by Expert}

From the results of the experts' validation, CVI values obtained on the content eligibility criteria were 0.91 , presentation $=0.93$, language $=0.86$, and aspects of student assignments $=0.9$. These results indicate that experts provide an excellent level of approval for content validity. Overall, the average CVI of the four criteria assessed by experts was 0.9.

Table 4. Content validity index for writing academic textbook by experts

\begin{tabular}{|c|c|c|c|c|c|}
\hline Criteria & Item description & $\begin{array}{c}\text { Relevant } \\
\text { (rating 3 \& 4) }\end{array}$ & $\begin{array}{l}\text { Not relevant } \\
\text { (rating } 1 \text { \& 2) }\end{array}$ & CVIa & Interpretation \\
\hline \multirow[t]{9}{*}{$\begin{array}{l}\text { Content } \\
\text { eligibility }\end{array}$} & $\begin{array}{c}\text { The material according to } \\
\text { core competency/basic } \\
\text { competency }\end{array}$ & 4 & 1 & 0.8 & Appropriate \\
\hline & $\begin{array}{c}\text { The material following } \\
\text { learning objectives }\end{array}$ & 5 & O & 1 & Appropriate \\
\hline & The truth of the concept & 4 & 1 & 0.8 & Appropriate \\
\hline & Simple reading theme & 5 & O & 1 & Appropriate \\
\hline & Contextual & 5 & O & 1 & Appropriate \\
\hline & Easy to understand & 5 & O & 1 & Appropriate \\
\hline & $\begin{array}{l}\text { Following the level of } \\
\text { student development }\end{array}$ & 5 & O & 1 & Appropriate \\
\hline & $\begin{array}{l}\text { Illustration supports the } \\
\text { concept }\end{array}$ & 4 & 1 & 0.8 & Appropriate \\
\hline & $\begin{array}{l}\text { Be present in features and } \\
\text { references }\end{array}$ & 4 & 1 & 0.8 & Appropriate \\
\hline \multicolumn{3}{|c|}{ Average CVI } & \multicolumn{3}{|c|}{$\mathbf{0 . 9 1}$} \\
\hline \multirow[t]{10}{*}{ Presentation } & Conceptual noise & 5 & $\mathrm{O}$ & 1 & Appropriate \\
\hline & Balance between parts & 5 & O & 1 & Appropriate \\
\hline & Student-centered & 5 & $\mathrm{O}$ & 1 & Appropriate \\
\hline & Variation in presentation & 5 & O & 1 & Appropriate \\
\hline & $\begin{array}{l}\text { Following the process genre } \\
\text { approach }\end{array}$ & 5 & O & 1 & Appropriate \\
\hline & Provide learning stimuli & 4 & 1 & 0.8 & Appropriate \\
\hline & Interesting interest & 4 & 1 & 0.8 & Appropriate \\
\hline & $\begin{array}{l}\text { Pictures/illustrations } \\
\text { following the theme }\end{array}$ & 5 & o & 1 & Appropriate \\
\hline & $\begin{array}{l}\text { Following the level of } \\
\text { student development }\end{array}$ & 4 & 1 & 0.8 & Appropriate \\
\hline & \multicolumn{2}{|l|}{ Average CVI } & \multicolumn{3}{|c|}{$\mathbf{0 . 9 3}$} \\
\hline Language & $\begin{array}{l}\text { Following the level of } \\
\text { thinking of students }\end{array}$ & 4 & 1 & 0.8 & Appropriate \\
\hline
\end{tabular}




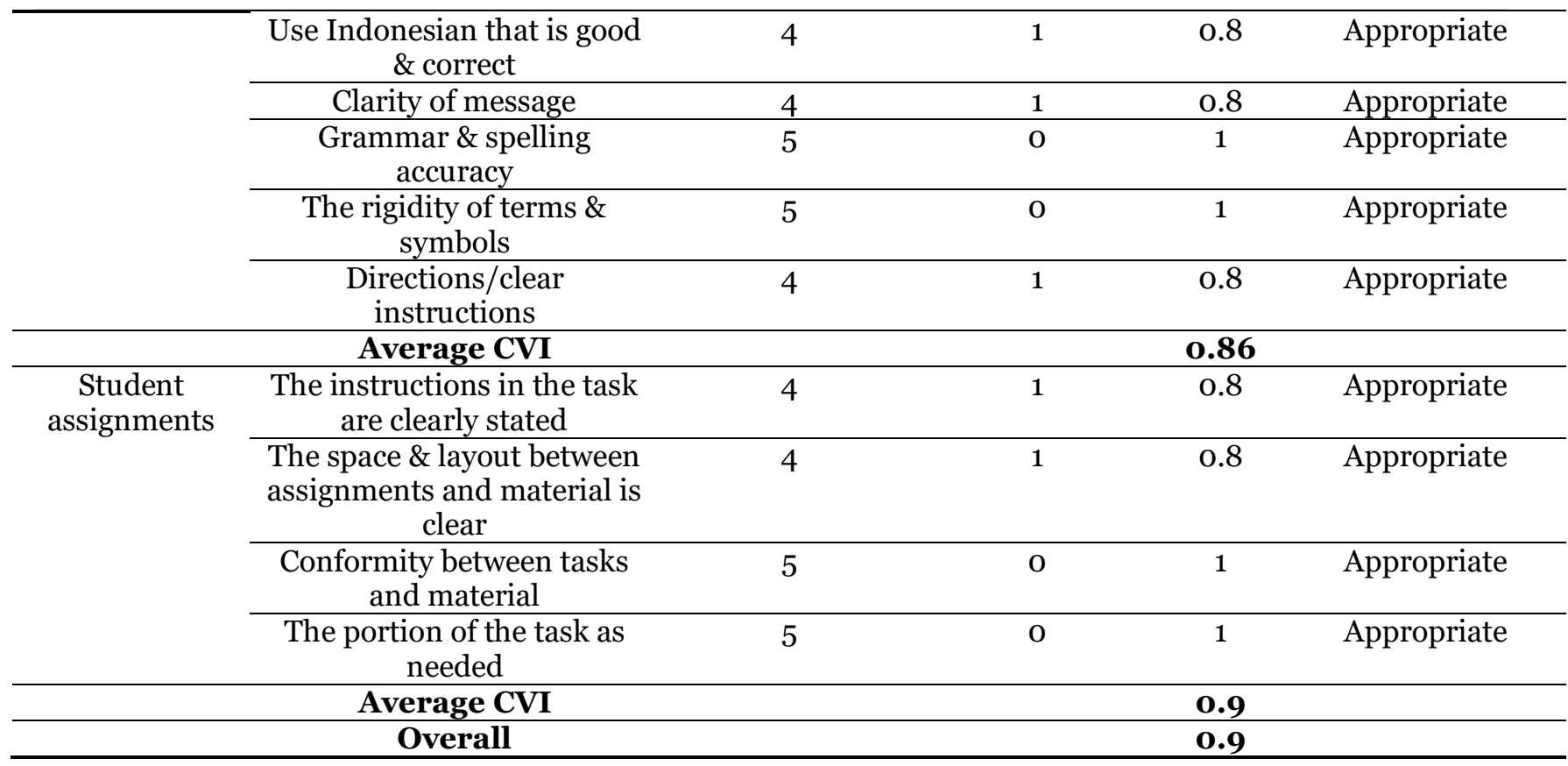

Even though the total CVI reaches 0.9 (right), there are some suggestions and inputs suggested by experts. Experts gave these suggestions at the end of each validation questionnaire sheet. The textbook does not require significant revisions, but only many improvements are categorized into minor changes. Some of these improvements include grammar, sentence structure, and some words that are incorrect in typing.

Writing is a language skill that is very important for students. It is based on the fact that the academic environment always requires students to write correctly and adequately. The students realize that writing skills are very much needed in getting a job in the future (Elsaid Mohammed \& Nur, 2018). Besides getting a job, writing skills also play a role in improving students' literacy skills in writing (Sabarun, 2019).

Some indications from the interviews and questionnaires narrowed to the need for a genre process approach in learning academic writing. The genre process approach combines three methods in learning to write, namely the product, process, and genre-based method. The combination of these three approaches aims to minimize the various deficiencies that exist so that learning objectives can be achieved maximally (Badger \& White, 2000) (Zhao, 2017) (Du, 2015).

The two researchers stated that assessing students' academic writing so far tends to use assessment tools in analyzing vocabulary errors only. Aspects of assessment in learning to write is also an essential aspect that teachers must focus on. The teacher suggested designing an assessment rubric that is not always focused on the linguistic aspect based on the interview results. Previous researchers also stated similar things (Rakedzon \& Baram-Tsabari, 2017; Storch \& Tapper, 2009). In compiling the assessment rubric, the teacher refers to various theoretical approaches that focus on the features of discourse and linguistics and the specific rules of academic writing. For this reason, it is necessary to assess all aspects of writing learning, which include: (1) content (relevant ideas), (2) writing organization (structure and coherence), (3) language use (vocabulary and grammar choices), and (4) the use of mechanical aspects (reading \& spelling).

In compiling the assessment rubric, the teacher refers to various theoretical approaches that focus on the features of discourse and linguistics and the specific rules of academic writing. For this reason, it is necessary to assess all aspects of writing learning, which include: (1) content (relevant ideas), (2) writing organization (structure and coherence), (3) language use (vocabulary and grammar choices), and (4) the use of mechanical aspects (reading \& spelling) (Tuyen et al., 2018).

From the results of interviews and questionnaires, the majority of respondents expect a stage of publication of the text they produce. The steps in learning to write do not end at the assessment 
process conducted by the teacher. Text publications are carried out to inform the reality of the field by providing a genuinely in-depth perspective (Smiles \& Short, 2006). For the academic environment, the importance of publication is needed because it relates to career advancement and the professional form of their work (Derntl, 2014) (Cardenas, 2014).

After obtaining initial information in the needs analysis phase, the developer (researcher) continues its activities to the next phase, namely the design phase. This phase is a phase to design products according to field needs. The design phase is carried out through several stages, such as (1) reference test construction, (2) media selection, (3) format selection, (4) protocol material, (5) source management format, (6) mastery-learning format, and (7) self-instructional format (Thiagarajan et al., 1974). Istiqomah (2016) describes this design phase with stages that are not much different, such as (1) collecting learning materials, (2) the process and preparation of teaching materials, (3) conceptualizing learning materials, and (4) compiling learning materials.

In obtaining the value of validity, researchers distributed questionnaires to experts to assess the textbook. The questionnaire data were analyzed to get the value of the Content Validity Index (CVI). Several studies use CVI in determining the validity of their products, including adult physical activity education modules (Lau et al., 2019), STEM modules for secondary schools (Kasim \& Ahmad, 2018), basic statistics modules for prospective teacher students (Setambah et al., 2017), and problem-based training modules for nursing education students (Sathya \& Reddemma, 2017).

The CVI value is considered to have good content validity if it reaches 0.80 or more (Rubio et al., 2003). CVI is calculated based on the number of experts who agree divided by the number of experts appointed (Lynn, 1986) (Rubio et al., 2003) (Lau et al., 2019). The expert recommendations state that at least five experts are involved in the validation process to avoid accidental agreements (Zamanzadeh et al., 2015). The experts were selected from various scientific disciplines, including academic writing learning experts, language education, and learning device development experts. Masuwai et al. (2016) stated that the diversity of scientific disciplines of the experts was intended to produce a variety of ideas in providing input and advice.

The CVI test results in this study indicate that the validity of the content in academic writing textbooks can be accepted from the expert's point of view. The average value of CVI on aspects of content eligibility is 0.9, presentation is 0.93, language is 0.86 , and student assignments are 0.9. Overall, the average total CVI of the textbook is 0.9. Thus, the writing textbook is stated to have the right level of validity based on the judgment of experts.

One of the essential aspects of research is the novelty that is found. Based on the research gap that has been described in the background of the problem can be emphasized that this research has a novelty. The existence of a writing learning textbook by adopting a process-genre approach is a novelty in this research. Although several studies have been developing learning tools (textbooks), the majority use a genre approach or a process approach. Meanwhile, textbooks combining process and genre approaches are still rarely found, primarily writing for college-level students.

\section{CONCLUSION}

This study seeks to develop and validate academic writing textbooks in Indonesian language courses at universities in Indonesia. The results showed that students and lecturers needed textbooks in academic writing lessons that could help them to improve their writing skills. In addition, the design of academic writing textbooks is based on the results of a needs analysis by paying attention to aspects of content, language, and presentation so that students easily understand it. In the validation test, the results of the study show that this textbook is declared valid. The validation process involved five experts in writing learning, language education, and experts in developing learning tools to obtain validity and reliability. The content validity index (CVI) score in the validation process is 0.9. The CVI is categorized as applicable because it reaches points above 0.79. Thus, the textbook is declared suitable for use in the learning process of academic writing in tertiary institutions. 


\section{REFERENCES}

Akinwamide, T. K. (2012). The influence of process approach in ESL students' performance in essay writing. Journal of English Language Teaching, 5, 16-29. http://dx.doi.org/10.5539/elt.v5n3p16

Alabere, R. A., \& Shapii, A. (2019). The effects of process-genre approach on academic writing. JEES (Journal of English Educators Society), $\quad 4(2), \quad 89-98$. https://doi.org/10.21070/jees.v4i2.2598

Al-Saggaf, M. A., Al-Aqad, M. H., \& Govindasamy, V. (2020). The key factors affecting English reading comprehension among Malaysian students. Psychology and Education Journal, 57(9), 2496-2503.

Amine, B., \& Faiza, S. (2018). The effect of process-genre approach on esp students' achievement in writing business letters. European Journal of Research and Reflection in Educational Sciences, 6(2), 10-14.

Ananth, A. \& Maistry, S. (2020). Invoking interactive qualitative analysis as a methodology in statistics education research. The Journal of Transdisciplinary Research in Southern Africa, 16(1), 1-12. doi:104102/td.v16i1.786

Andrews, R. (2009). Argumentation in higher education: Improving practice through theory and research. Routledge.

Babalola, \& Litinin, H. A. (2012). Effects of process-genre based approach on the written english performance of computer science students in a Nigerian polytechnic. Journal of Education and Practice, 3(6), $1-7$.

Bada, E. \& Okan, Z. (2000). Students' language learning preferences. The Electronic Journal for English As A Second Language, 4(3), 1-14.

Badger, R., \& White, G. (2000). A process genre approach to teaching writing. ELT Journal, 54(2), 153-160. https://doi.org/10.1093/elt/54.2.153

Bargate, K. (2014). Interactive qualitative analysis-a novel methodology for qualitative research. Mediterranian Journal of Social Science, 5(20), 11-19.

Boroujeni, S. A., \& Fard, F. M. (2013). A needs analysis of english for specific purposes (esp) course for adoption of communicative language teaching: (A case of Iranian first-year students of educational administration). International Journal of Humanities and Social Science Invention, 2(6), 35-44. Retrieved from www.ijhssi.org

Cardenas, M. L. (2014). Publishing and academic writing: Experiences of authors who have published in profile. PROFILE, 16(2), 11-20.

Chee Keong, Y., \& Mussa, I. H. (2015). Academic writing difficulties of Iraqi postgraduate students in Malaysia. International Journal of Education and Research, 3(6), 25-34.

Coe, M., Hanita, M., Nishioka, V., \& Smiley, R. (2011). An investigation of the impact of the $6+1$ trait writing model on grade 5 student writing achievement. Department of Education United State of America

Cothran, D. J., Kulinna, P. H., \& Garrahy, D. A. (2003). This is kind of giving a secret away: Students' perspective on effective class management. Teaching and Teacher Education, 19(4), 435444 .

Derntl, M. (2014). Basics of paper writing and publishing. International Journal of Technology Enhanced Learning, 6(J2), 105-123.

Dewle, M. (2017). Why genre-based approach should be used to teach academic writing in Indian context? Journal of Chemical Information and Modeling, 4(1-9), 1689-1699. https://doi.org/10.1017/CBO9781107415324.004

$\mathrm{Du}, \mathrm{B}$. (2015). Raising process-genre awareness: A proposal of esp writing lesson plan. Creative Education, 6(April), 631-639.

Elsaid Mohammed, A. S., \& Nur, H. S. M. (2018). Needs analysis in english for academic purposes: The case of teaching assistants at the university of Khartoum. How, 25(2), 49-68. https://doi.org/10.19183/how.25.2.409

Fraenkel, J. R., Wallen, N. E., \& Hyun, H. H. (2012). How to design and evaluate research in education. McGraw-Hill.

Ganobcsik-Williams, L. (2006). Teaching academic writing in UK higher education. Palgrave Macmillan.

Gupitasari, H. (2013). The implementation of process-genre approach to teaching writing business 
letter. Journal of English and Education, 1(1), 89-95.

Guthrie, K. H. (2019). "Nothing is ever easy": Parent perceptions of intensity in their gifted adolescent children. The Qualitative Report, 24(8), 2080-2101.

Heffernan, N. (2006). An integrated approach to teaching academic writing. Asian EFL Journal, $8(3), 249-258$.

Hutchinson, T., \& Waters, A. (1987). English for spesific purposes: A learning-centered approach. Cambridge University Press.

Istiqomah, I. (2016). The development of learning material: Explanation text based on multimodal by using sway app in $11^{\text {th }}$ grade of sman 1 Batu. International Journal of Educational Research, 4(9), 313-322.

Ivanic, R., \& Lea, M. R. (2006). New contexts, new challenges: The teaching of writing in UK higher education. In Ganobcsik-Williams (Ed.), Teaching academic writing in uk higher education: Theories, Practices and Models. Macmillan Publishing Company.

Jahin, J. H. (2012). The effect of peer reviewing on writing apprehension and essay writing ability of prospective efl. Teachers Australian Journal of Teacher Education, 37(11), 60-84.

Kasim, N. H., \& Ahmad, C. N. C. (2018). Pro-stem module: The development and validation. International Journal of Academic Research in Business and Social Sciences, 8(1), 728-739. https://doi.org/10.6007/ijarbss/v8-i1/3843

Knight, S., Buckingham Shum, S., Ryan, P., Sandor, Á., \& Wang, X. (2018). Designing academic writing analytics for civil law student self-assessment. International Journal of Artificial Intelligence in Education, 28(1), 1-28. https://doi.org/10.1007/s40593-016-0121-o

Kuswandari, A.H., Slamet, S.Y., \& Setiawan, B. (2018). Kontribusi kemampuan berpikir kritis sebagai konstruksi peningkatan keteramilan menulis esai. Gramatika: Jurnal Penelitian Pendidikan Bahasa dan Sastra Indonesia, 4(1), 173-183. doi:10.22202/jg.2018.v4i1.2410

Lau, X. C., Wong, Y. L., Wong, J. E., Koh, D., Sedek, R., Jamil, A. T., ... Poh, B. K. (2019). Development and validation of a physical activity educational module for overweight and obese adolescents: cergas programme. International Journal of Environmental Research and Public Health, 16(9), 1-16. https://doi.org/10.3390/ijerph16091506

Lilis, T., \& Turner, J. (2001). Students writing in higher education: Contemporary confusion, traditional concerns. Teaching in Higher Education, 6(1), 57-68.

Lynn, M. R. (1986). Determination and quantification of content validity. Nursing Research, 36(6), $382-385$.

Masuwai, A., Tajudin, M., \& Saad, N. S. (2016). Evaluating the face and content validity of a teaching and learning guiding principles instrument (tlgpi): A perspective study of Malaysian teacher educators. Geografia: Malaysian Journal of Society \& Space, 12(3), 11-21.

Mccrimmon, M. (2005). High school writing practices in the age of standards: Implications for college composition teaching english in the two year college. Urbana, 32, 248-260.

National Education Standards Agency (2014). The 2014 textbook instruments. Jakarta: BNSP

Percy, W., Kostere, K., \& Kostere, S. (2015). Generic qualitative research in psychology. The Qualitative Report, 2O(2), 76-85.

Rakedzon, T., \& Baram-Tsabari, A. (2017). To make a long story short: A rubric for assessing graduate students' academic and popular science writing skills. Assessing Writing, 32, 2842. doi:10.1016/j.asw.2016.12.004

Rubio, D. M. G., Berg-Weger, M., Tebb, S. S., Lee, E. S., \& Rauch, S. (2003). Objectifyng content validity: Conducting a content validity study in social work research. ProQuest Psychology Journals, 27(2), 94-104. https://doi.org/10.1093/swr/27.2.94

Sabarun, S. (2019). Needs analysis on developing efl paragraph writing materials at Kalimantan 12 learners. English Language Teaching, 12(1), 186. https://doi.org/10.5539/ elt.v12n1p186

Salim, N.A., Walker, Z.M., \& Rosenblatt, K. (2016). Teacher perceptions on the effectiveness of a process-genre approach on the writing skills of students with dyslexia. Asia Pasific Journal of Developmental Differences, 3(1), 35-61. doi:10.3850/S2345734114000217

Sarala, T., Fauziah, B. I., \& Rahim, B. S. A. (2015). Role of model essays in developing students writing skills in Malaysian schools: A review of literature. Mediterranian Journal of Social Sciences, 6(2), 56-61.

Sathya, P., \& Reddemma, K. (2017). Development of problem based learning training module in nursing education. International Journal of Research in Medical Sciences, 5(5), 1986. 
https://doi.org/10.18203/2320-6012.ijrms20171830

Setambah, M. A. B., Tajudin, N. M., Adnan, M., \& Saad, M. I. M. (2017). Adventure based learning module: Content validity and reliability process. International Journal of Academic Research in Business and Social Sciences, 7(2), 615. https://doi.org/10.6007 /IJARBSS/v7i2/2669

Singer, E., \& Couper, M. P. (2017). Some methodological uses of responses to open questions and other verbatim comments in quantitative surveys. Methods, Data, Analyses, 11(2), 1-19. https://doi.org/10.12758/mda.2017.01

Smiles, T. L., \& Short, K. G. (2006). Transforming teacher voice through writing publication. Teacher Education Quarterly, 33(3), 133-147.

Storch, N. \& Tapper, J. (2009). The impact of an EAP course on postgraduate writing. Journal of English for Academic Purposes, 83(3), 2017-2023.

Taherdost, H. (2016). sampling methods in research methodology: How to choose a sampling technique for research. International Journal of Academic Research in Management, 5(2), 18-27.

Tesfie, A. (2017). Teachers' cognition on process genre approach and practice of teaching writing skills in EFL context. English for Spesific Purposes World, 54(19), 1-17.

Tuyen, T., Osman, S., Ahmad, N.S., Dan, T.C. (2018). Developing and validating scoring rubric for the assessment of recovery papers writing ability of EFL/ESL undergraduate students: The effect of research papers writing intervention program using process genre model of research paper. Journal of Language, Literature, Culture and Education, 1(1), 1-17.

Thiagarajan, S., Semmel, D. S., \& Semmel, M. I. (1974). Instructional development for training teachers of exceptional children. Indiana University.

Ulla, M. B., \& Winitkun, D. (2017). Thai learners' linguistic needs and language skills: Implications for curriculum development. International Journal of Instruction, 10(4), 203-220. https://doi.org/10.12973/iji.2017.10412a

Wilkinson, D., \& Birmingham, P. (2003). Using research instruments: A guide for researchers. RoutledgeFalmer.

$\mathrm{Xu}, \mathrm{X} .$, \& Xuemei, L. (2018). Teaching academic writing through a process-genre approach: A pedagogical exploration of an EAP program in China. The Electronic Journal for English as a Second Language, 22(2), 1-21.

Yanghee, K., \& Jiyoung, K. (2005). Teaching Korean university writing class: Balancing the process and genre approach. Asian EFL Journal, 7(2), 1-15. Retrieved from http://asian-efljournal.com/1280/quarterly-journal/2005/o6/teaching-korean-university-writing-classbalancing-the-process-and-the-genre-approach/

Yanti, N., Suhartono, S., \& Hiasa, F. (2018). Keterampilan menulis akademik mahasiswa s-1 program studi pendidikan bahasa dan sastra Indonesia fkip universitas Bengkulu. Silampari Bisa: Jurnal Penelitian Pendidikan Bahasa Indonesia, Daerah, dan Asing, 1(1), 1-16.

Zamanzadeh, V., Ghahramanian, A., Rassouli, M., Abbaszadeh, A., Alavi-Majd, H., \& Nikanfar, A.R. (2015). Design and implementation content validity study: Development of an instrument for measuring patient-centered communication. Journal of Caring Sciences, 4(2), 165-178. https://doi.org/10.15171/jcs.2015.017

Zhao, S. (2017). On the application of the process-genre approach to teaching English writing. 2017 3rd Annual International Conference on Modern Education and Social Science, 495-499. DEStech Publication. 